SCIENCE AND SOCIAL CHANGE

IN BRITAIN AND EUROPE

$1700-1900$ 


\title{
SCIENCE AND SOCIAL CHANGE IN BRITAIN AND EUROPE
}

\author{
$1700-1900$
}

Colin A. Russell 
ISBN 978-0-333-29273-0 ISBN 978-1-349-17271-9 (eBook)

DOI 10.1007/978-1-349-17271-9

(C) Colin A. Russell 1983

Softcover reprint of the hardcover 1st edition 1983 978-0-333-29272-3

All rights reserved. For information, write:

St. Martin's Press, Inc., 175 Fifth Avenue, New York, NY 10010

Published in the United Kingdom by The Macmillan Press Ltd. First published in the United States of America in 1983

ISBN 978-0-312-70239-7

Library of Congress Cataloging in Publication Data Russell, Colin Archibald.

Science and social change in Britain and Europe, $1700-1900$.

Bibliography: $p$.

Includes indexes.

1. Science-Social aspects-Great Britain-History.

2. Science-Social aspects-Europe-History. I. Title.

Q175.52.G7R87 $1983 \quad 303.4{ }^{\prime} 83 \quad 83-11021$

ISBN 978-0-312-70239-7 


\section{Contents}

List of Figures viii

List of Plates $\quad$ ix

General Editor's Preface xii

Preface xiii

Abbreviations xvi

1 Approaching the Problem 1

2 The Shape of Enlightenment Science 13

2.2 'Laws sublimely simple' 16

2.3 Science in the Shadow of Newton 20

3 Nature in the Enlightenment

3.1 Nature and Ideology 33

3.2 Nature and Man $\quad 35$

3.3 Nature and God $\quad 41$

4 Nature and Society

4.1 'His marvellous Providence' 49

4.2 Newtonianism as a Political Weapon 52

4.3 Some Alternatives to Newtonianism 61

5 The Social Organisation of Enlightenment Science

5.1 Royal Science 69

5.2 Private Patronage of Science 76

5.3 Virtuosi and Collectors 80 
5.4 Scientific Training on the Continent 85

5.5 The Special Case of Scotland 89

6 Science in the Early Industrial Revolution

6.1 Introduction 96

6.2 The Chemical Revolution 99

6.3 Institutionalised Science in the Industrial Revolution

7 Interlude: Change and Continuity in French Science

7.1 Aristocratic Science, 1789-1793

7.2 Democratic Science, 1793-1795

7.3 Bureaucratic Science, 1795-1799

7.4 Imperial Science, 1799-1815

8 Radical Science in Britain, 1790-1830

9 Science for the Masses, 1825-1850

9.1 The Demolished Staircase

9.2 New Routes to Science in England 154

9.3 The Rhetoric of Useful Science 160

9.4 The Mythology of Social Control 165

9.5 The Symbolism of Progress 171

10 Strongholds of Amateur Science in England

10.1 'Not the Land of Science'?

10.2 The 'Lit. and Phil.' Movement

10.3 The Natural History Movement

10.4 The British Association

11 The Rise of the Specialist

11.1 Language and Institutions 193

11.2 Geology for Gentlemen? 195

11.3 Chemistry for Chemists 203

11.4 Specialists Overseas 212

12 The Road to Professionalisation

12.1 Science as a Profession 220

12.2 The first Institute for Professional Science 226

12.3 Postscript: through a glass darkly 231

13 The State and Science

13.1 Pressures for Government Support 
CONTENTS

vii

13.2 Opposition to Government Support

241

13.3 The Conclusion of the Matter

245

14 Epilogue: Science Triumphant?

254

Notes and References

260

Bibliography

291

Indexes

294 
viii

\section{List of Figures}

Figures

Figure 1 Numbers of Chemists and Chemical Laboratories in Germany, 1700-1800

Figure 2 H. Boerhaave and Scottish Science

Figure 3 French Manufacture of Gunpower

Figure 4 The Leblanc Process

Figure 5 Lectures to the Newcastle Lit. and Phil., 1830-1858

Figure 6 Dates of Formation of National Scientific Societies

Figure 7 Membership of the Institution of Mechanical Engineers, 1840-80 


\section{List of Plates}

1. Priestley's chemical apparatus.

2. Eighteenth-century electrical machines. From Priestley's History of Electricity.

3. Natural history cabinet.

4. The starry heavens. From James Harvey, Medications and Contemplations (1796).

5. Instrument makers' workshop. From the Encyclopedie (1767).

6. Eighteenth-century chemical laboratory. From C. Singer, The Earliest Chemical Industry (1948).

7. Sulphuric acid manufacture. From C. Singer, The Earliest Chemical Industry.

8. Cartoon of Joseph Priestley.

9. 'Church and King' riots.

10. The Royal Institution.

11. The title page of the Mechanics' Magazine.

12. The Manchester Mechanics' Institution. From the Jubilee Book of the Manchester College of Technology.

13. A laboratory in the London Mechanics' Institution. From the Mechanics' Magazine.

14. The Sheffield Mechanics' Institute. From the Illustrated London News.

15. The Leeds Mechanics' Institute. From the Illustrated London News.

16. The Newcastle Literary and Philosophical Society Building. From R. S. Watson, History of the Literary and Philosophical Society of Newcastle (1897). 
17. The Royal College of Chemistry.

18. The Felling Chemical Works. From the Penny Magazine.

19. The Leblanc rotary convertor. From G. Lunge, Manufacture of Sulphuric Acid and Alkali.

20. The Crystal Palace Exhibition. From the Illustrated London News.

21. Exhibition commissioners.

22. Darwin's funeral. From The Graphic.

The author and publisher wish to thank the following illustration sources: The Science Museum - 1; The British Library - 3; The Evangelical Library - 4; The British Museum - 5; The Mansell Collection - 8, 9; The Royal Institution - 10; The Archives of Imperial College of Science and Technology, London - 17; The Victoria and Albert Museum - 21. 


\section{TO MY FATHER \\ AND IN MEMORY \\ OF MY MOTHER}




\section{General Editor's Preface}

SINCE the Second World War there has been a massive expansion in the study of economic and social history generating, and fuelled by, new journals, new academic series and societies. The expansion of research has given rise to new debates and ferocious controversies. This series proposes to take up some of the current issues in historical debate and explore them in a comparative framework.

Historians, of course, are principally concerned with unique events, and they can be inclined to wrap themselves in the isolating greatcoats of their 'country' and their 'period'. It is at least arguable, however, that a comparison of events, or a comparison of the way in which different societies coped with a similar problem - war, industrialisation, population growth and so forth - can reveal new perspectives and new questions. The authors of the volumes in this series have each taken an issue to explore in such a comparative framework. The books are not designed to be path-breaking monographs, though most will contain a degree of new research. The intention is, by exploring problems across national boundaries, to encourage students in tertiary education, in sixth-forms, and hopefully also the more general reader, to think critically about aspects of past developments. No author can maintain strict objectivity; nor can he or she provide definitive answers to all the questions which they explore. If the authors generate discussion and increase perception, then their task is well done.

Clive Emsley 


\section{Preface}

STUDIES of science in its social context have become so fashionable in recent years that historical analyses of internal developments within the sciences have become comparatively rare. Combined with this trend has been a proliferation of highly specialised studies of great interest to scholars in the field, but unfortunately inaccessible to a wider public. In this respect the History of Science is in some danger of becoming a victim of its own new-found professionalism. For some years one has searched publishers' lists anxiously, but in vain, for works on the present subject that could reasonably be expected to serve as a general introduction or as student texts. It was this gap in the literature, more than any other consideration, that goaded a rather reluctant author into producing the present book. It is intended for any who are seriously concerned to study the historical dimensions of the relations between science and society, whether approaching the subject from general history or from science itself. Some ten years' experience at the Open University has persuaded me that such an enterprise, though apparently foolhardy, is indeed possible, and that the common ground between historians and scientists is surprisingly great.

The theme of this book is the multitude of ways in which science has reflected, influenced and indeed become part of the wider phenomena of social change. Considerations of length have limited the period to a mere two centuries, and also concentrated attention largely on one country, Britain, though 
attempts have been made to place the British experience in a wider international context. An area that has been covered far less thoroughly than I should have wished is the impact of science on living and working conditions, and on the means of destroying or prolonging life. Adequate treatment of these themes would require another book-length study.

Warm thanks are offered to the staffs of many institutions including the Public Record Office, the British Library, The Wellcome Historical Medical Library, Bedfordshire County Library, Bedford Central Library, Lancaster Public Library, Newcastle City Library, and the Libraries of the Open University, the University of London, the Royal Society of Chemistry, Guildhall, London and Preston Polytechnic. I am grateful to the Royal Institution for permission to cite the manuscript notebook of Thomas Webster and to Mr George Rolleston for permission to quote from a Davy letter in his possession; also to the Harvester Press for permission to make extensive citations from The Newtonians and the English Revolution 1689 to 1720 , by Margaret Jacob. Acknowledgement for illustrations will be found on page $\mathrm{x}$.

It will be apparent that my debt to other scholars is enormous, especially to those represented in the footnotes. I can only hope that none have been misrepresented, especially when I have disagreed with their conclusions. One work above all others has been a catalyst, inspiration and (in some respects) a model. Its excellence has at the same time relieved me of the necessity of covering much of the same ground: Donald Cardwell's The Organisation of Science in England, 2nd edn (London: Heinemann, 1972).

I am most grateful to several colleagues who have read and criticised parts of the book: Dr John H. Brooke, Dr Robert Fox and Dr Gerrylynn K. Roberts, and especially to the Editor of this series, Mr Clive Emsley, whose comments on the whole manuscript have been invaluable. Needless to say the responsibility for what follows is mine alone.

My thanks must also go to Dr Eamann Duffy for allowing me to see a manuscript version of his forthcoming paper on 'The Whiston circle and heterodoxy'; to Dr Robert Fox for showing me an as yet unpublished essay on the profession of science in nineteenth-century France; and to Dr Jim Moore for 
a pre-publication copy of his paper on the burial of Charles Darwin in Westminster Abbey.

Nor must I forget the often passionate debates with colleagues at the Open University where many of these issues first became sharpened in my own mind. To them all I am very grateful, as I am to the Open University for a year of study leave during which this book took shape. My gratitude also goes to our two secretaries in the History of Science group, Mrs Patricia Dixon and Mrs Stephanie Lansdown, who between them have coped valiantly with innumerable drafts of chapters and the collection and collation of appropriate illustrations.

Finally, I have to thank my family who have had to live for far too long with my preoccupation with the book but who have nevertheless exhibited monumental patience and understanding.

COLIN A. RUSSELL

The Open University

Milton Keynes 
xvi

\section{Abbreviations}

Amer. Hist. Rev.

Ann. Sci.

B. J. Hist. Sci.

Berichte

Biol. J. Linnaen Soc.

Bull. Inst. Hist. Res.

Chem. Age

Chem. and Ind.

Chem. Brit.

Chem. News

$D N B$

$D S B$

Econ. Hist. Rev.

Hist. J.

Hist. Sci.

Hist. Stud. Phys. Sci.

J. Chem. Educ.

J. Hist. Ideas

J. Roy. Inst. Chem.

J. Roy. Soc. Arts

J. Soc. Bibliography Nat. Hist.

J. Soc. Chem. Ind. M. E B. Lab. Bull.
American Historical Review

Annals of Science

British Journal for the History of Science

Berichte der Deutschen chemischen

Gesellschaft

Biological Journal of the Linnaen

Society

Bulletin of the Institute of Historical

Research

Chemical Age

Chemistry and Industry

Chemistry in Britain

Chemical News

Dictionary of National Biography

Dictionary of Scientific Biography

Economic History Review

Historical Journal

History of Science

Historical Studies in the Physical Sciences

Journal of Chemical Education

Journal of the History of Ideas

Journal of the Royal Institute of

Chemistry

Journal of the Royal Society of Arts

Journal of the Society for the Bibliography of

Natural History

Journal of the Society of Chemical Industry

May and Baker Laboratory Bulletin 
Med. Hist.

Notes and Records

Oxford Rev. Educ.

Proc. Chem. Soc.

Proc. Inst. Chem.

Proc. Roy. Inst.

Proc. Roy. Soc. Edinburgh

Qu. J. Chem. Soc.

Qu. J. Geol. Soc.

Rep. Brit. Assoc. Adv. Sci.

Soc. Stud. Sci.

Trans. Newcastle Chem.

Soc.

Trans. Newcomen Soc.

Trans. Roy. Geol. Soc. Cornwall

Trans. Roy. Soc. Edinburgh

Trans. Tyne Chem. Soc.
Medical History

Notes and Records of the Royal Society

Oxford Review of Education

Proceedings of the Chemical Society

Proceedings of the Institute of Chemistry

Proceedings of the Royal Institution

Proceedings of the Royal Society of Edinburgh

Quarterly Journal of the Chemical Society

Quarterly Journal of the Geological Society

Reports of the British Association for the Advancement of Science

Social Studies of Science

Transactions of the Newcastle Chemical Society

Transactions of the Newcomen Society

Transactions of the Royal Geological Society of Cornwall

Transactions of the Royal Society of Edinburgh

Transactions of the Tyne Chemical Society

\section{SUPPLEMENTARY LIST OF ABBREVIATIONS}

$A d v$. Sci.

B. J. Educ. Studies.

Comptes Rendus

Eng. Hist. Rev.

J. Brit. Astronom. Assoc.

J. Soc. Arts.

J. Soc. Hist.

J. Textile Inst.

Proc. Roy. Soc.

Trans. Beds. Nat. Hist. Soc.
Advances in Science

British Journal of Educational Studies

Comptes Rendus Lebdonadaires des Séances de l'Académie des Sciences (Paris)

English Historical Review

Journal of the British Astronomical Association

Journal of the Society of Arts

Journal of Social History

Journal of the Textile Institutions

Proceedings of the Royal Society of London

Transactions of the Bedfordshire Natural History Society 